\title{
Petrology of the Plutonic Rocks at the XIV Iron-Oxide Prospect, Bafq Mining District, Central Iran
}

\author{
Samira Bakhtiyari ${ }^{1}$, Mohammad Lotfi $^{2 *}$, Nima Nezafati ${ }^{1}$, Arash Gourabjeripour $^{3}$ \\ ${ }^{1}$ Department of Geology, Science and Research Branch, Islamic Azad University, Tehran, Iran \\ ${ }^{2}$ Department of Geology, North Tehran Branch, Islamic Azad University, Tehran, Iran \\ ${ }^{3}$ Department of Geology, Myianeh Branch, Islamic Azad University, Myianeh, Iran \\ Email: *M_lotfi_1014@yahoo.com
}

How to cite this paper: Bakhtiyari, S., Lotfi, M., Nezafati, N. and Gourabjeripour, A. (2016) Petrology of the Plutonic Rocks at the XIV Iron-Oxide Prospect, Bafq Mining District, Central Iran. Open Journal of Geology, 6, 1591-1604.

http://dx.doi.org/10.4236/ojg.2016.612113

Received: November 7, 2016

Accepted: December 26, 2016

Published: December 29, 2016

Copyright (๑) 2016 by authors and Scientific Research Publishing Inc. This work is licensed under the Creative Commons Attribution International License (CC BY 4.0).

http://creativecommons.org/licenses/by/4.0/

\begin{abstract}
The XIV iron-oxide prospect in the northern part of the Bafq mining district is hosted by intrusive rocks and demonstrates similar characteristics with Kiruna mineralization. The plutonic complex of the XIV prospect is composed of two major types of intrusive rocks, including: 1) a granitic intrusive body which is itself composed of two types; a pale-pink leucogranite and a white-gray aplite, as well as 2) a gabbrodiorite intrusive body. Geochemically, these rocks are tholeitic-calcalkaline and metaluminous in nature. Geochemical characteristics of the plutonic rocks of the study area support a non-orogenic continental setting.
\end{abstract}

\section{Keywords}

Granite, Gabbrodiorite, Geochemistry, Petrography, Bafq, Iron

\section{Introduction}

The Bafq mining district in Central Iran is the most important iron metallogenic province in the region and a significant district on a worldwide basis ([1]-[9]). The Bafq district, extending from Bafq to Saghand, is part of the central Iranian microplate which is now embedded within the Alpine-Himalayan orogenic system. The Central Iranian Terrane is an assemblage of several Precambrian fragments of Gondwanaland which covers an approximately $230,000 \mathrm{~km}^{2}$ of moderate relief surrounded by Mesozoic-Cenozoic fold-and-thrust belts of the Alpine-Himalayan system.

The Central Iranian Terrane consists, from east to west, of three major crustal domains: the Lut Block, Tabas Block and the Yazd Block. These blocks are separated by a 
series of intersecting regional-scale faults. The Tabas and Yazd blocks are separated by a more than $1000 \mathrm{~km}$ long and up to $80 \mathrm{~km}$ wide arcuate and structurally complex belt composed of variably deformed supracrustal rocks, i.e. the Kashmar-Kerman Tectonic Zone [7] which hosts the Bafq mining district. The Kashmar-Kerman Tectonic Zone provides remarkable exposures of the deeper sections of the Central Iranian platform strata, among which the Late Neoproterozoic and Early Paleozoic rocks are abundant [7] [8].

The XIV iron prospect (geographic coordinate: $55^{\circ} 28^{\prime} \mathrm{E}-55^{\circ} 30^{\prime} \mathrm{E}$ and $32^{\circ} 04^{\prime} \mathrm{N}$ $32^{\circ} 07^{\prime} \mathrm{N}$ ) is located at $8 \mathrm{~km}$ north of Chah Gaz magnetite deposit (anomaly XIVA) and $60 \mathrm{~km}$ north of Bafq city (Figure 1). This prospect is divided into three ore zones (northern, central and southern orebodies). According to the data obtained from drilling cores, the main orebody (northern zone) is continued down to $300 \mathrm{~m}$ below surface. The magnetite consists of $62 \%$ iron and is phosphorus-poor. The northern ore zone mainly occurs in an aplite dome (caused by late differentiation of granite and called "leuco-metasomatite" in mining terminology) and is composed of the massive magnetite and hematite ore bodies together with actinolite, all of which are located in the northern and southern parts of the area. The origin of the Bafq district deposits has been the subject of longstanding debate and remains controversial. Also, the XIV ironprospect has received little attention so far. This paper presents the outcome of the preliminary petrological investigations on the plutonic rocks of the prospect which partly hosts the mineralization. In this regard, the different rock types of the so called Zarigan granite at the prospect have been studied using petrographic and geochemical investigations and have been interpreted accordingly the tectonic setting.

\section{Research Methodology}

During the field observations, 120 rock samples were collected from different parts of the study area, of which 80 thin sections and 34 polished thin sections were prepared and studied using polarizing microscope. 12 samples from granite and gabbrodiorite intrusive bodies were analyzed for their geochemistry (including REEs) using ICP-MS and XRF. The petrographic and geochemical results were then interpreted for understanding the petrology of the intrusive rocks in the study area.

\section{Results and Discussion}

\subsection{Granites}

The Zarigan intrusion is the largest intrusive body exposed in the study area. This intrusion is a shallow, leucocratic body that ranges in texture and color from a typical medium-crystalline granite to a sub-volcanic granite porphyry (aplite) (Figure 2(a) \& Figure 3(a)) [10]. The first type granites (Leucogranite) are pale-pink (Figure 2(a) \& Figure 2(b)) and tend to be alkali granites and have a granular and pertitic texture. The studied granite samples consist primarily of quartz (39\%), orthoclase (35\%) and plagioclase (oligoclase) (25\%) in approximately equal proportions. Accessory minerals include biotite, hornblende, titanite, zircon, and opaque minerals (Figure 2(a)). This 


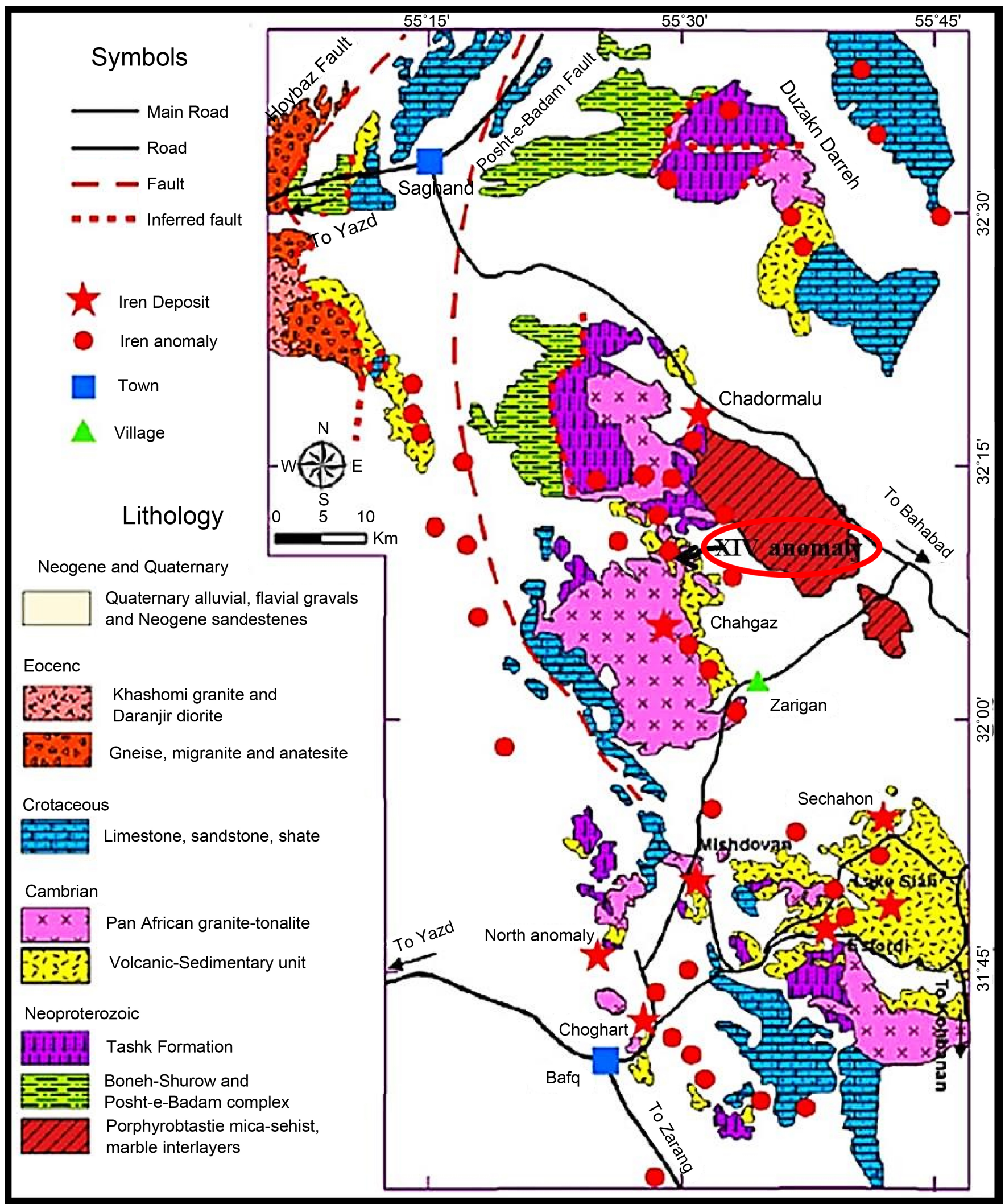

Figure 1. Simplified geological map of the Bafq mining district indicating the location of the XIV iron prospect (Modified from Haghipour, 1977; NISCO, 1980; Ramezani \& Tucker, 2003) [9]-[15]. 

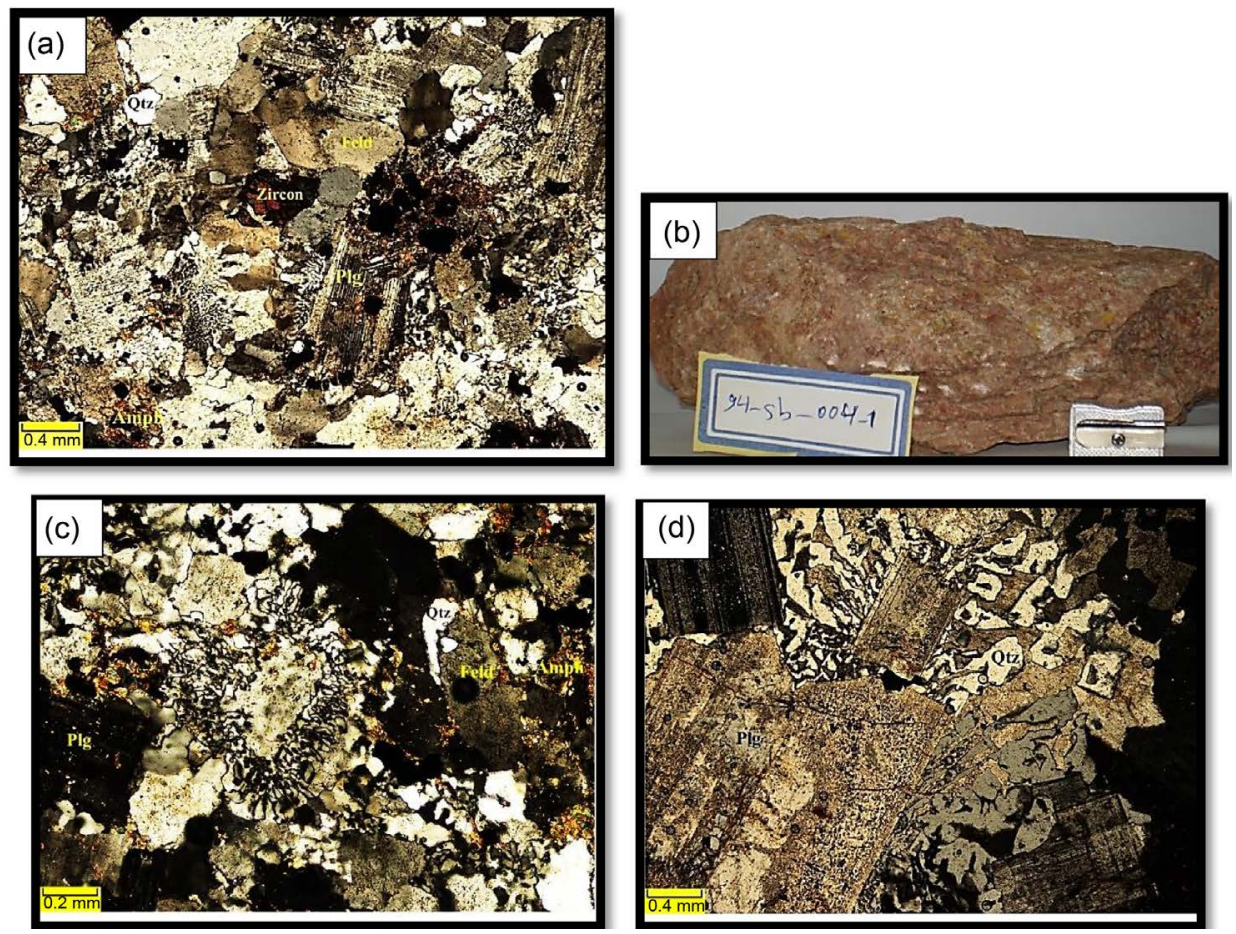

Figure 2. (a) Photomicrographs of (leuco) granite of Zarigan (XPL). (b) Hand specimen of the second type of granite. (c) and (d) Inequigranular, hypidiomorph granular, granophyric and myrmekitic textures of Leucogranite.

granite displays a variety of textures. The general texture of the Leucogranite is inequigranular hypidiomorph granular, poikilitic (Figure 2(c)) myrmekitic (Figure 2(c) \& Figure 2(d)) and graphic with granophyric quartz-albite intergrowths.

Eutectic intergrowth of quartz with sodic feldspar is often of the granophyric and rarely of the micrographic type and has just been observed sporadically. In some Leucogranite samples of the XIV prospect, the granophyric texture is developed and the whole rock is composed of this type of intergrowth. Alkali feldspar in granophyres is typically of albite type that has been altered to sericite.

The second type of granite is a white to gray aplite (sub-volcanic granite porphyry orlate differentiation phase of Zarigan granite which is called "leuco-metasomatite" in mining terminology) (Figure 3(b)). The major rock forming minerals of the aplite of the XIV prospect consist of quartz $(70 \%-85 \%)$ and sodic feldspar $(15 \%)$, while the accessory minerals includezircon, apatite, hornblende and opaque minerals. Quartz crystals are seen as individual texture and comprise two distinct textural components: 1) a fine grained (up to few millimeters) broadly equigranular alkali feldspar and plagioclase component; 2) a fine to medium grained component (Figure 3(c)); sometimes intergrown with albite and rarely with pertite. These types of quartz crystals have formed simultaneously.

\subsection{Gabbrodiorites}

The modal mineralogical composition of representative gabbrodiorite samples (Figure 4(a)) 


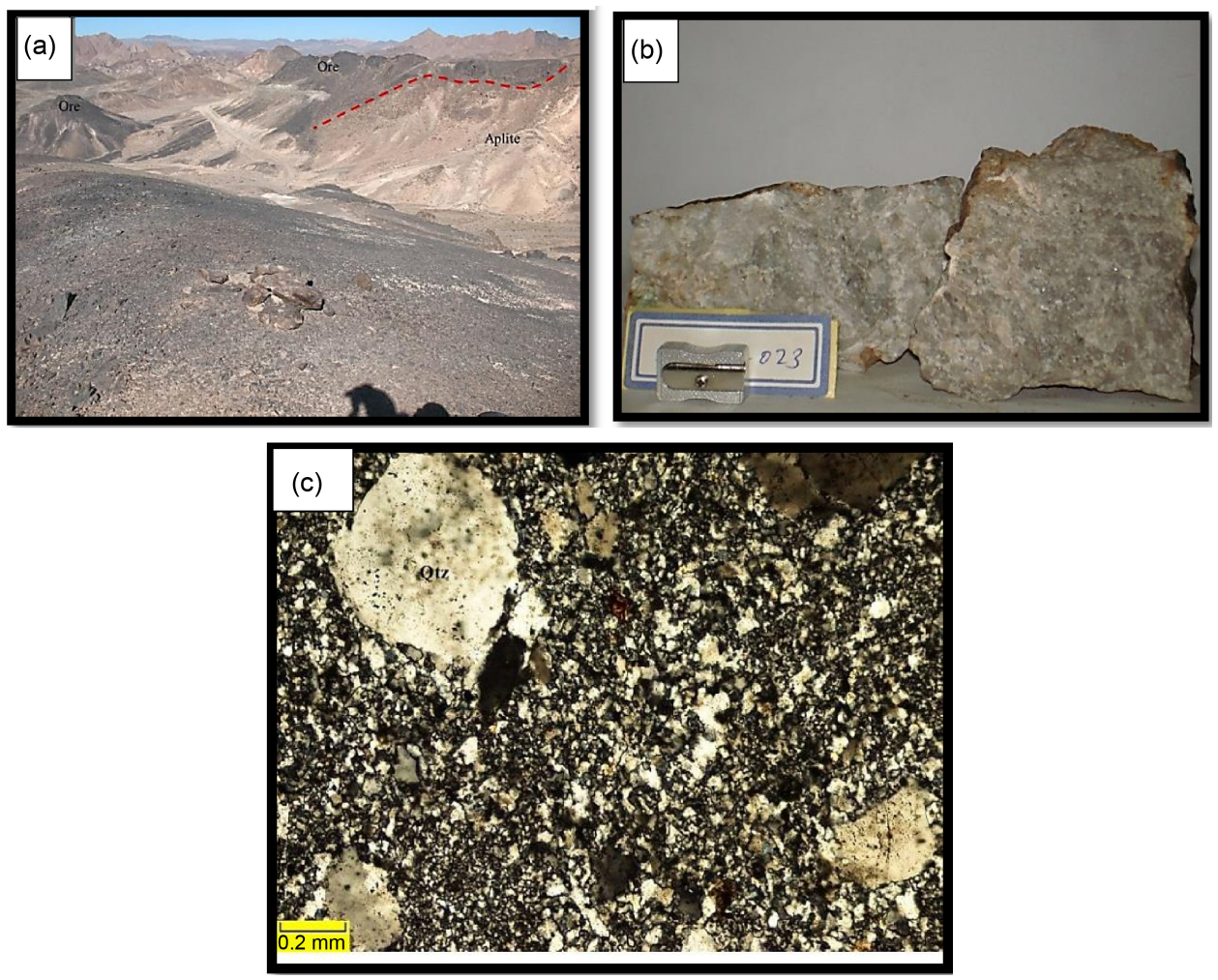

Figure 3. (a) Outcrop of the aplite dome, in north of the XIV prospect. (b) Hand specimen of the first type of granite. (c) Anhedral to subhedral quartz crystals are seen as individual crystals with granular to cataclastic texture.

from the XIV prospect, demonstrates the major minerals of pyroxene $(25 \%-30 \%)$, amphibole $(10 \%-12 \%)$ and plagioclase (35\% - 40\%) (Figure 4 (b)) together with accessory minerals of biotite, apatite, olivine, zircon and opaque minerals (Figure 4(c)).

This gabbrodiorite indicates an inter-granular and hypidiomorph granular texture with fine-grained euhedral-subhedral magnetite scattering with pyroxene and plagioclase. The petrographic investigations show that most of theamphibole has converted to tremolite and actinolite. Also undeveloped granophyric quartz-albite intergrowth is observed in the gabbrodioritic rocks which indicate mixing between granite and gabbrodioritic rocks.

\subsection{Geochemistry}

The result of major element analyses of granite and gabbrodiorite samples are listed in Table 1 and Table 2. The alumina saturation index values [16] are plotted in Figure 5 and show that the least altered Zarigan granites are both Al-oversaturated (peraluminous) and Al-undersaturated (metaluminous), but most samples have been plotted in the peraluminous region. The felsic plutonic rocks of the region plot in the granite and alkali granite field, while the mafic plutonic rocks plot in the gabbro field of the plutonic rock classification diagram [17] (Figure 6). To distinguish between calcalkaline and tholeiitic suites, the samples were plotted in an AFM diagram (Figure 7) which shows 

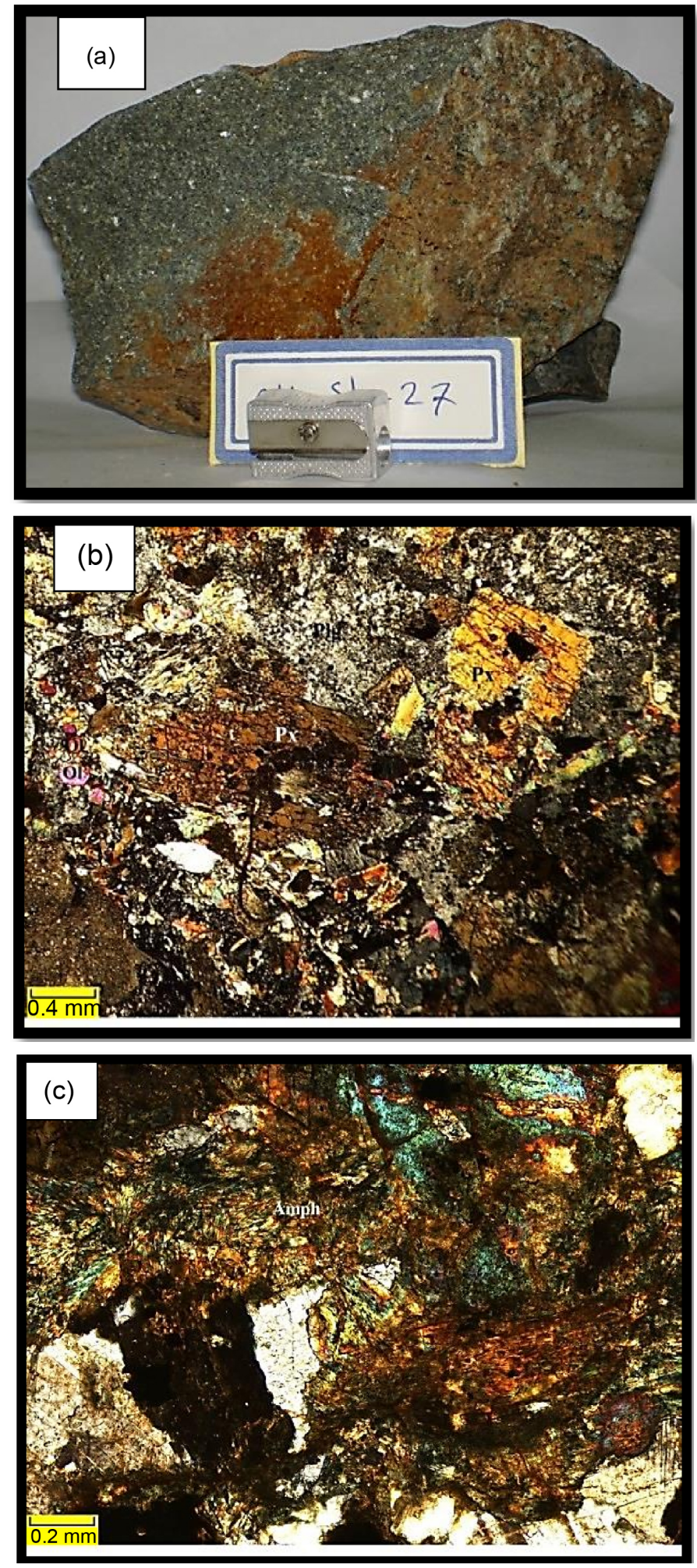

Figure 4. (a) Hand specimen of gabbrodiorite. (b) Photomicrographs of high grade alteration in pyroxene ((a), XPL and (b), PPL). (c) Photomicrographs of metasomatic amphibole filling the open spaces of highly altered plagioclase ((a), XPL and (b), PPL). 


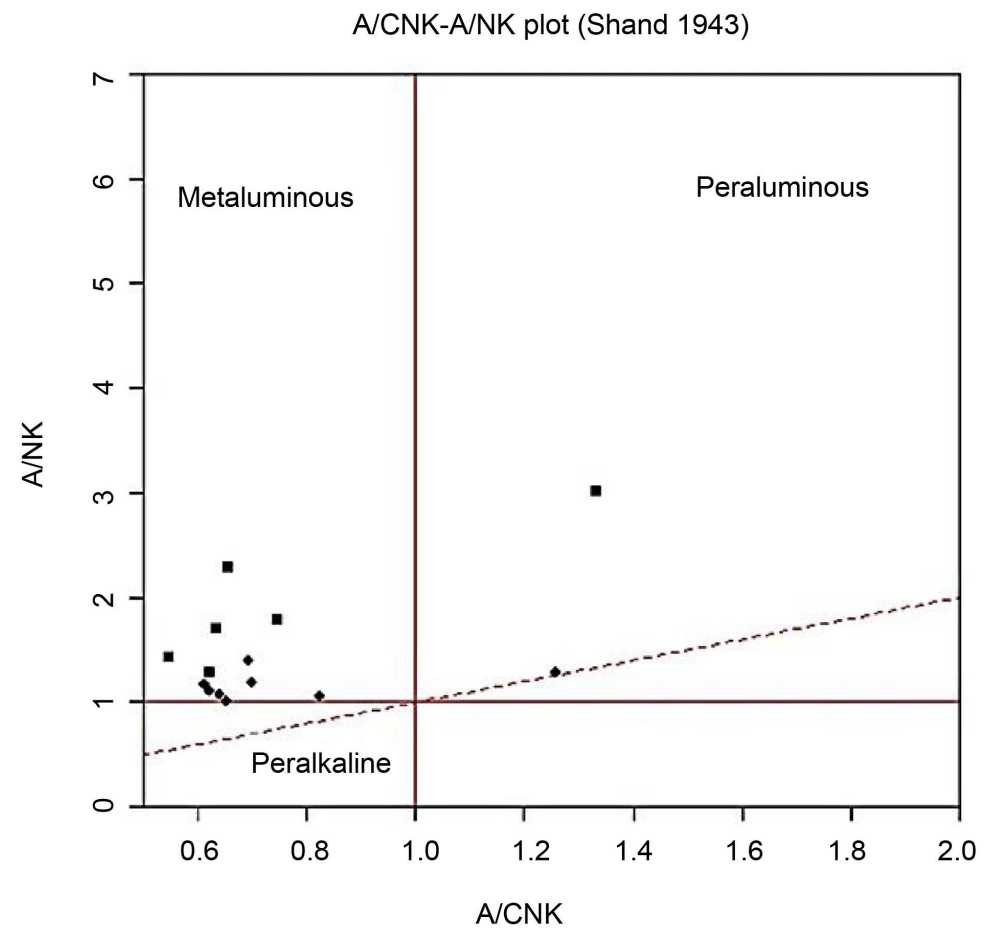

Figure 5. Al-saturation plot for granitoid rocks [16].

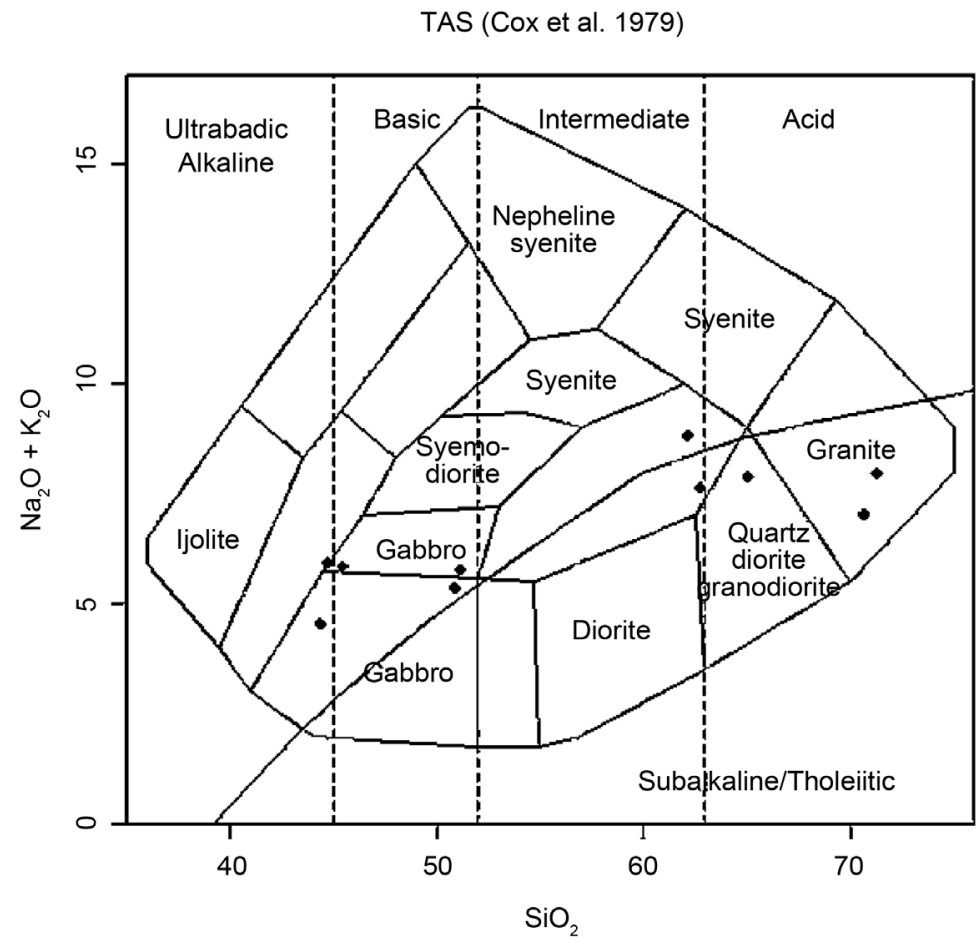

Figure 6. Classification of plutonic rocks [17].

that the samples mostly plot in contact between tholeiitic and calcalkaline field (Figure 7). 


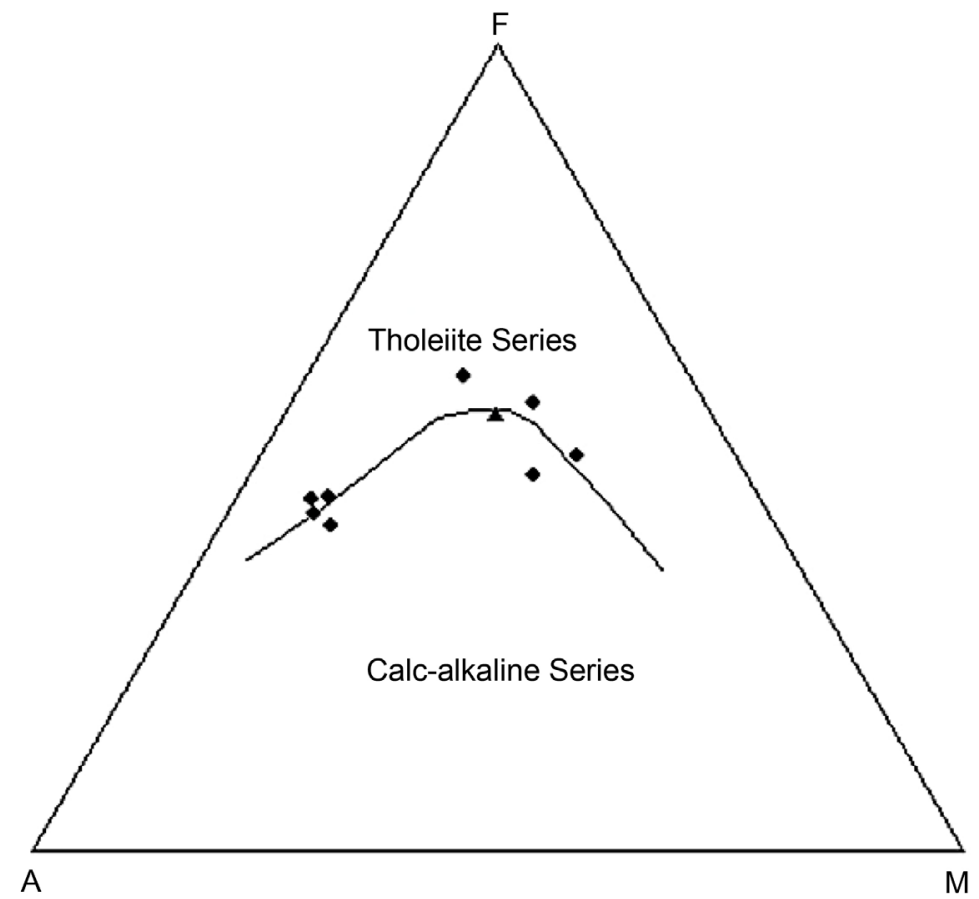

Figure 7. Discriminant diagram between tholeiitic and calcalkaline series of granitic rocks of the XIV prospect.

Table 1. Major element composition of the Zarigan granite (measured by XRF).

\begin{tabular}{cccccccccccc}
\hline Sample & $\mathrm{SiO}_{2}$ & $\mathrm{Al}_{2} \mathrm{O}_{3}$ & $\mathrm{CaO}$ & $\mathrm{MgO}$ & $\mathrm{Fe}_{2} \mathrm{O}_{3}$ & $\mathrm{P}_{2} \mathrm{O}_{5}$ & $\mathrm{TiO}_{2}$ & $\mathrm{Na}_{2} \mathrm{O}$ & $\mathrm{K}_{2} \mathrm{O}$ & $\mathrm{FeO}$ & $\mathrm{LOI}$ \\
\hline $\mathrm{Sb} 2$ & 65.11 & 13.02 & 1.92 & 1.52 & 3.51 & 0.41 & 0.85 & 6.78 & 1.07 & 3.59 & 1.08 \\
$\mathrm{Sb} 4$ & 70.77 & 12.29 & 4.72 & 0.1 & 1.29 & 0.27 & 0.05 & 6.45 & 0.55 & 1.28 & 2.26 \\
$\mathrm{Sb} 4 \mathrm{a}$ & 71.71 & 10.83 & 4.63 & 0.1 & 0.97 & & 0.05 & 0.05 & 8.5 & 0.77 & 2.15 \\
$\mathrm{Sb8}$ & 71.37 & 12.63 & 0.1 & 3.48 & 0.91 & 0.05 & 0.05 & 2.19 & 5.77 & 1.16 & 1.81 \\
$\mathrm{Sb} 10$ & 70.35 & 12.15 & 3.88 & 0.1 & 0.99 & 0.05 & 0.05 & 0.05 & 9.46 & 0.71 & 2.39 \\
$\mathrm{Sb} 17$ & 67.81 & 12.22 & 4.91 & 0.1 & 1.9 & 0.05 & & 0.05 & 8 & 1.69 & 3.12 \\
$\mathrm{Sb} 31$ & 71.13 & 16.41 & 0.35 & 1.53 & 0.99 & & 0.05 & 0.06 & 0.07 & 1.16 & 2.49 \\
\hline
\end{tabular}

Table 2. Major element composition of the gabbrodiorite (measured by XRF).

\begin{tabular}{cccccccccccc}
\hline Sample & $\mathrm{SiO}_{2}$ & $\mathrm{Al}_{2} \mathrm{O}_{3}$ & $\mathrm{CaO}$ & $\mathrm{MgO}$ & $\mathrm{Fe}_{2} \mathrm{O}_{3}$ & $\mathrm{P}_{2} \mathrm{O}_{5}$ & $\mathrm{TiO}_{2}$ & $\mathrm{Na}_{2} \mathrm{O}$ & $\mathrm{K}_{2} \mathrm{O}$ & $\mathrm{FeO}$ & $\mathrm{LOI}$ \\
\hline $\mathrm{Sb6}$ & 45.48 & 13.94 & 5.96 & 5.66 & 5.16 & 0.75 & 2.94 & 2.73 & 3.1 & 8.79 & 4.63 \\
$\mathrm{Sb7}$ & 44.45 & 14.74 & 8.82 & 6.45 & 4.83 & 0.87 & 2.05 & 2.71 & 1.83 & 9.39 & 2.66 \\
$\mathrm{Sb} 24$ & 51.78 & 15.52 & 7 & 2.07 & 3.65 & 0.96 & 1.09 & 5.85 & 2.38 & 3.66 & 3.54 \\
$\mathrm{Sb} 27$ & 48.42 & 15.72 & 3.61 & 9.47 & 4.69 & 0.64 & 1.8 & 3.14 & 0.05 & 8.33 & 3.36 \\
$\mathrm{Sb37}$ & 51.22 & 11.9 & 7.38 & 4.06 & 6.3 & 0.74 & 1.41 & 3.75 & 2 & 8.33 & 1.22 \\
\hline
\end{tabular}

The samples of the XIV granite have $\mathrm{SiO}_{2}$ contents of $62.8 \mathrm{wt} \%-72 \mathrm{wt} \%$ and $\mathrm{Al}_{2} \mathrm{O}_{3}$ contents of $11.99 \mathrm{wt} \%-16.41 \mathrm{wt} \%$ (Table 1 ) and are enriched in $\mathrm{Na}_{2} \mathrm{O}(2.19 \mathrm{wt} \%-6.78$ wt $\%$ ) and $\mathrm{K}_{2} \mathrm{O}(0.5 \mathrm{wt} \%-10.74 \mathrm{wt} \%)$, as it is demonstrated in the TAS diagram (Figure 6). These granites are metaluminous with alumina saturation index values (ASI = molar 
$\mathrm{Al}_{2} \mathrm{O}_{3} /\left(\mathrm{CaO}+\mathrm{Na}_{2} \mathrm{O}+\mathrm{K}_{2} \mathrm{O}\right)$ ) up to 1.10 (Figure 5) and are calcic as indicated by the Rittman index values between 0.8 and $1.4\left(\sigma=\left[\mathrm{Na}_{2} \mathrm{O}(\mathrm{wt} \%)+\mathrm{K}_{2} \mathrm{O}(\mathrm{wt} \%)\right] 2 /\left[\mathrm{SiO}_{2}\right.\right.$ $(w t \%)-43]$ ) and their position on $\mathrm{Na}_{2} \mathrm{O}+\mathrm{K}_{2} \mathrm{O}$ vs. $\mathrm{SiO}_{2}$ diagram [18]. There is a general decrease in $\mathrm{Al}_{2} \mathrm{O}_{3}, \mathrm{FeOt}$ and $\mathrm{CaO}$ with increasing $\mathrm{SiO}_{2}$ (Table 1).

The XIV granites have relatively high contents of LILE such as $\mathrm{Ba}$ and $\mathrm{Rb}$, and low HFSE contents with marked negative $\mathrm{Nb}, \mathrm{Sr}$ and $\mathrm{Ti}$ anomalies on MORB normalized spider diagram (Figure $8(\mathrm{~b})$ ). The chondrite normalized REE patterns show an enrichment in LREE relative to $\operatorname{HREE}((\mathrm{La} / \mathrm{Yb}) \mathrm{CN}=0.84-2.95)$, with negative $\mathrm{Eu}$ anomalies (Figure 8(a)). Similar to granites, the gabbrodiorites of the XIV prospect are depleted in HREE and relatively enriched in LREE ( $(\mathrm{La} / \mathrm{Yb}) \mathrm{CN}=3.2-23.5)$. Such patterns contrast sharply with those of granites in other sequences. Despite similar major and trace element compositions, there are subtle differences between the granite
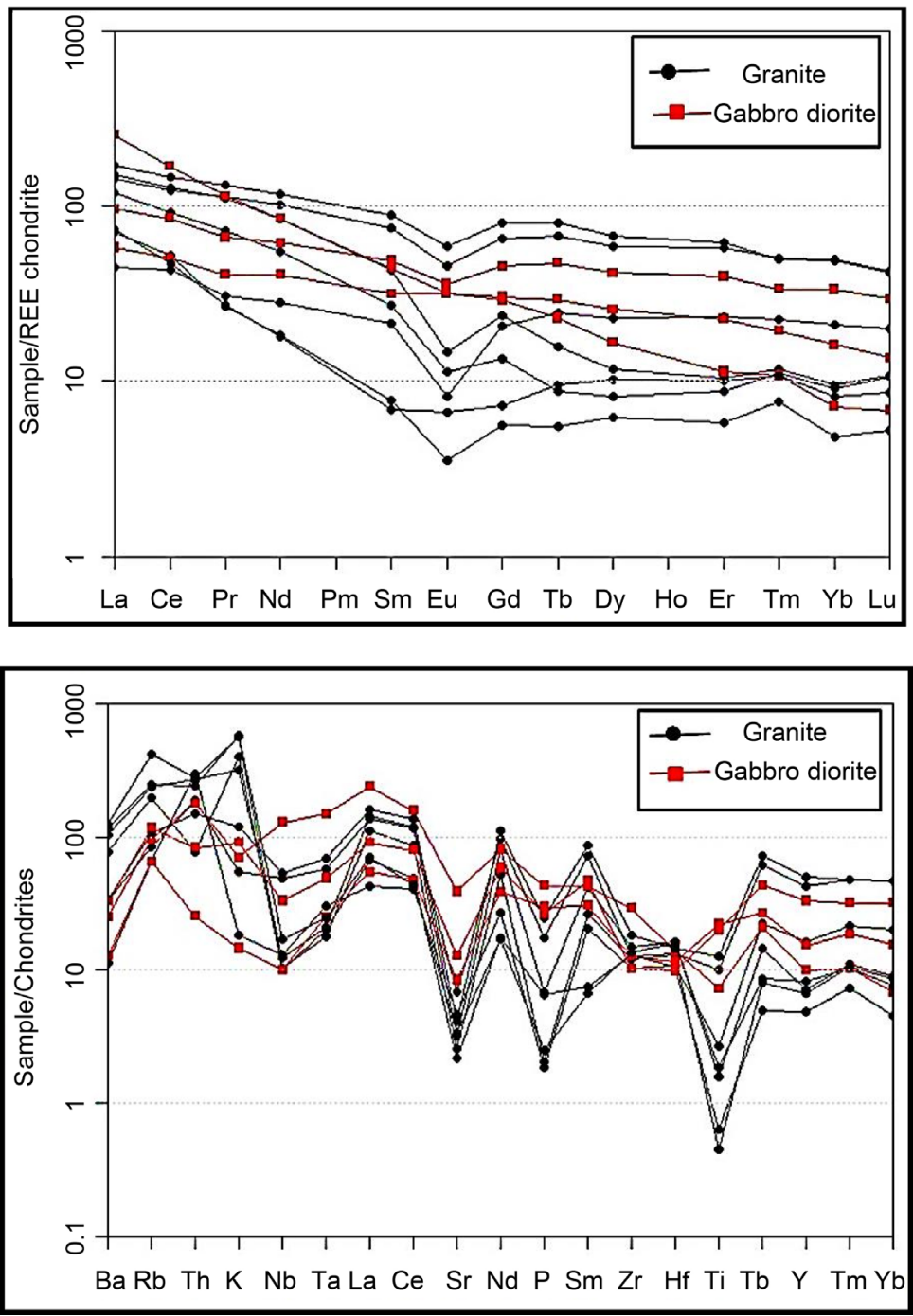

Figure 8. MORB normalized trace element patterns (down) and Chondrite-normalized rare earth elements (up) for the granite and gabbrodioriteof the XIV prospect. 
and gabbrodiorite of the XIV prospect. REE concentrations in the granite are higher than those in gabbrodiorites (Figure $8(\mathrm{a})$ ) and the granite has a higher $\mathrm{Th} / \mathrm{U}$ ratio $(2.5$ - 7.4) than that of the gabbrodiorite $(0.7$ - 3.52). The gabbrodiorite of the XIV prospect have lower contents of $\mathrm{SiO}_{2}$ (44.45 to $\left.51.22 \mathrm{wt} \%\right)$ and $\mathrm{K}_{2} \mathrm{O}$ (0.05 to $\left.3.1 \mathrm{wt} \%\right)$ rather than those of granite. Chondrite normalized REE patterns for the XIV gabbrodiorite show wide compositional variations (Figure 8(a)). They are depleted in HREE and relatively enriched in LREE with LREE/HREE ratios of 4.3 to 42 , and have narrow compositional variation with negetive Eu anomalies (Figure 8(a)).

\subsection{Tectonic Setting: Anorogenic or Post-Orogenic?}

The host rocks of the XIV prospect area, according to this study and the study conducted by Ramezani and Tucker [13], vary from granite to gabbrodiorite, indicating an alkaline-sub-alkaline or a bimodal composition. The tectonic setting diagrams (Figure 9) illustrate volcanic arc granites.

Boron is an interesting trace element, as it is strongly enriched in seawater and marine sediments compared with its concentration in most crust and mantle rock types [19]. Therefore, boron can be used as a tracer to indicate the presence of subducted sediment or altered oceanic crust in magma's source regions. Boron concentration gener-
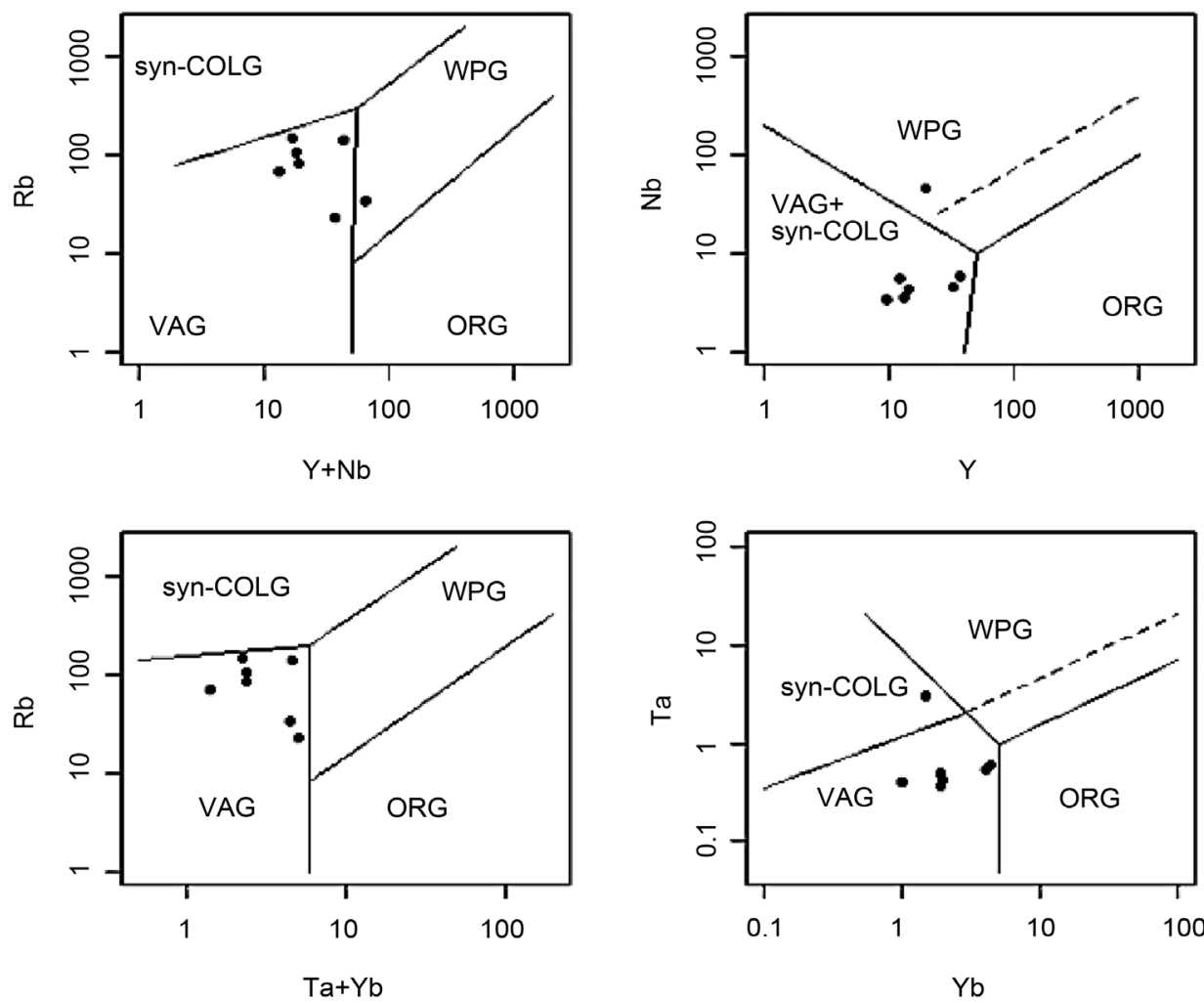

Figure 9. Plot of granitoid rocks from the XIV prospect on the $\mathrm{Y}+\mathrm{Nb}$ vs. $\mathrm{Rb} \& \mathrm{Y}$ vs. $\mathrm{Nb} \& \mathrm{~Tb}+$ $\mathrm{Yb}$ vs. $\mathrm{Rb} \& \mathrm{Yb}$ vs. Ta discrimination diagram of Pearce et al. [20]. Abbreviations of fields: VAG: volcanic arc granites; WPG: within plate granites; Syn-COLG: Syn-collisional granites; ORG: ocean ridge granites; Post-COLG: post-collision granites. 
ally varies from 1 to $2 \mathrm{ppm}$ in mid-ocean ridges and ocean island basalts, but, frequently reaches to more than $10 \mathrm{ppm}$ in volcanic arc basalts and andesites. No boron was detected in this study or those conducted by Ramezani and Tucker [13] and Isfahani and Sharifi [21] probably indicating an orogenic continental rift setting for the Bafq region.

The plutonic rocks of the Bafq region are diverse and range from granite to gabbrodiorites (bimodal composition). Many are identified as syenites and/or red granite (e.g. Sorkh granite in the vicinity of Chadormalu paleocrater) (Figure 1). These rocks generally display either potassic or sodic alteration and are pervasively replaced by hydrothermal hematite and magnetite. Extensive sodic, potassic, sericitic and silicic alterations are present at the XIV iron-oxide prospect and its associated iron deposits.

A conceptual conclusion by Hitzman et al. [22] (on the basis of Forster \& Knittle's data, 1979), suggests an extensional environment for the Bafq region. According to Aghanabati [23], Upper Precambrian-Lower Cambrian volcanic rocks in the Bafq region are alkaline and reflect a continental drift. In the absence of distinguishable contact between Late-Precambrian volcanicevaporite deposits and Early-Cambrian formations, Aghanabati [23] suggests a Late-Precambrian to Early-Cambrian age, extending into Middle Cambrian. Samani [24] proposed an intra-continental rift facies (Saghand Formation), comprising five members with different lithologies and bimodal volcanism. According to Momenzadeh [25] and Feiznia [26], a volcanic activity introduced ions and volatile components in an early rift basin and evaporate deposition occurred during an early to intermediate rifting stage. Moore and Modabberi [27] also proposed bimodal volcanism and immature nonmarine clastic sediments in an anorogenic continental drift.

Emami [28] proposed a within plate magmasim at the Chadormalu-Saghand area, again, a non-orogenic continental rift environment associated with tholeiitic, alkaline-subalkaline or undersaturated-saturated or bimodal volcanism; and LREE enrichment [27] [29] [30]. According to Hall [31] and Raymond [32], in those island arcs that are not underlained by continental crust, andesites are associated with abundant basalts (e.g. shoshonitic basalts) and scarce dacites and rhyolite, but, in volcanic regions underlined by continental crust, they are associated with less abundant basalts and voluminous dacites and rhyolites; in other words, unlike orogenic belts, where intermediate igneous rocks are commonplace, the anorogenic continental areas are characterized by a bimodal association of rhyolite and basalt, or granite and gabbrodiorite; that is, continental rift basalts typically are accompanied by more siliceous volcanic rocks ranging from andesite to rhyolite in composition, but the volcanic rock suites are commonly bimodal consisting mainly of two basalt and rhyolite types. Sillitoe [33] proposed that, in arc environments (e.g. IOCG deposits), shoshonitic basalt, basalt, basaltic andesite and high $\mathrm{K}$ calc-alkaline series are dominant, while dacite and rhyolite are rare. In other words, there is a tholeiitic-calc-alkaline bimodal composition which is dominant at these environments. In contrary, alkaline-sub alkaline bimodal suites occur in anorogenic continental rift settings [27] [29] [30] [31] [32] [34].

The collected evidence in this study shows that the host rocks (bimodal series) con- 
tain voluminous intermediate-felsic intrusive and extrusive rocks (andesite-daciterhyolite) with lesser mafic igneous rocks, i.e. non-orogenic environment (B-type), as suggested by Hitzman [35].

\section{Conclusions}

The Zarigan granite is one of the most important plutonic rocks in the study area. This intrusion is a shallow, leucocratic body that ranges in texture and colors from a typical medium-crystalline granite to sub-volcanic granite porphyry (aplite). Mineral assemblage in these rocks is quartz, $\mathrm{K}$-feldspar, plagioclases, biotite, chlorite and opaque minerals. The alumina saturation index values [19] show that Zarigan granites are Alundersaturated (metaluminous), while these felsic plutonic rocks of the region plot in the granite and alkali granite field of the plutonic rock classification diagram [18].

Other important group is gabbrodiorite which contains pyroxene $(25 \%-30 \%)$, amphibole $(10 \%-12 \%)$ and plagioclase $(35 \%-40 \%)$, and some accessory minerals like biotite, apatite, olivine, zircon and opaque minerals. Also, Gabbrodiorite shows an inter-granular and hypidiomorph granular texture with fine-grained euhedral-subhedral magnetite scattering with pyroxene and plagioclase.

Plutonic rocks from the XIV prospect are similar in their REE patterns. They are depleted in HREE and relatively enriched in LREE with LREE/HREE ratios of 4.3 to 42 , and have narrow compositional variation with negative Eu anomalies.

The collected evidence in this study shows that the host rocks (bimodal series) contain voluminous intermediate-felsic intrusive bodies which have occurred in a nonorogenic environment.

\section{Acknowledgements}

The present study is based on the first author's $\mathrm{PhD}$ thesis at the Science and Research branch of the Islamic Azad University, Tehran, Iran. The authors would like to thank the editor and referees for their critiques and suggestions that helped to improve the quality of the paper. This work was supported by the Iran Minerals Production \& Supply Co. (IMPASCO) and IMIDRO. The authors express their gratitude to the managers of the ICIOC (Iranian Central Iron Ore Co.) and Chah Gaz mine for permission to access to the deposit and sampling and support during field work.

\section{References}

[1] Barton, M.D. and Johnson, D.A. (1996) Evaporitic-Source Model for Igneous-Related Fe Oxide-(REE-Cu-Au-U) Mineralization. Geology, 24, 259-262. https://doi.org/10.1130/0091-7613(1996)024<0259:ESMFIR>2.3.CO;2

[2] Williams, P.J., Barton, M.D., Fontboté, L., de Haller, A., Johnson, D.A., Mark, G., Marschik, R. and Oliver, N.H.S. (2005) Iron-Oxide-Copper-Gold Deposits: Geology, Space-Time Distribution and Possible Modes of Origin. Economic Geology, 100 th Anniversary, 371-405.

[3] Jami, M., Dunlop, A.C. and Cohen, D.R. (2007) Fluid Inclusion and Stable Isotope Study of the Esfordi Apatite-Magnetite Deposit, Central Iran. Economic Geology, 102, 1111-1128. https://doi.org/10.2113/gsecongeo.102.6.1111 
[4] Torab, F.M. and Lehmann, B. (2007) Magnetite-Apatite Deposits of the Bafq District, Central Iran: Apatite Geochemistry and Monazite Geochronology. Mineralogical Magazine, 71, 347-363. https://doi.org/10.1180/minmag.2007.071.3.347

[5] Daliran, F. (2002) Kiruna-Type Iron Oxide-Apatite Ores and Apatitites of the Bafq District, Iran, with an Emphasis on the REE Geochemistry of Their Apatites. In: Porter, T.M., Ed., Hydrothermal Iron Oxide Coppergold and Related Deposits. A Global Perspective, Vol. 1, PGC Publishing, Adelaide, 303-320.

[6] Stosch, H.G., Romer, R.L., Daliran, F. and Rhede, D. (2011) Uranium-Lead Ages of Apatite from Iron Oxide Ores of the Bafq District, East-Central Iran. Mineralium Deposita, 46, 921. https://doi.org/10.1007/s00126-010-0309-4

[7] Torab, F. (2008) Geochemistry and Metallogeny of Magnetite-Apatite Deposits of the Bafq Mining District, Central Iran. Unpublished PhD Thesis, Clausthal University of Technology, Lower Saxony.

[8] Jami, M. (2005) Geology, Geochemistry and Evolution of the Esfordi Phosphate-Iron Deposit, Bafq Area, Central Iran. Unpublished PhD Thesis, The University of New South Wales, Sydney.

[9] Nabatian, G.H., Rastad, E., Neubauer, F., Honarmand, M. and Ghaderi, M. (2015) Iron and Fe-Mn Mineralisation in Iran: Implications for Tethyan Metallogeny. Australian Journal of Earth Sciences: An International Geoscience Journal of the Geological Society of Australia, 62, 211-241. https://doi.org/10.1080/08120099.2015.1002001

[10] Ramezani, J. and Tucker, R.D. (2003) The Saghand Region, Central Iran: U-Pb Geochronology, Petrogenesis and Implications for Gondwana Tectonics. American Journal of Science, 303, 622-665. https://doi.org/10.2475/ajs.303.7.622

[11] Samani, B. (1993) Saghand Formation: A Riftogenic Unit of Upper Precambrian in Central Iran. Geological Survay of Iran, Geoscience Scientific Quarterly Journal, 2, 32-45. (In Farsi with English abstract)

[12] Haghipour, A. (1977) Geological Map of the Biabanak-Bafq Area (Scale 1:500,000). Geological Survey of Iran.

[13] NISCO (1980) Result of Search and Valuation Works at Magnetic Anomalies of the Bafq Iron Ore Region during 1976-1979. Unpublished Report, National Iranian Steel Corporation, 260 p.

[14] Ramezani, J. (1997) Regional Geology, Geochronology and Geochemistry of the Igneousand Metamorphic Rock Suites of the Saghand Area, Central Iran. Unpublished PhD Thesis, Washington University, Saint Louis, Missouri, 416 p.

[15] Ahmadipour, H. and Rostamizadeh, G. (2012) Geochemical Aspects of Na-Metasomatism in Sargaz Granitic Intrusion (South of Kerman Province, Iran). Journal of Sciences, Islamic Republic of Iran, 23, 45-58.

[16] Shand, S.J. (1943) Eruptive Rocks. Their Genesis, Composition, Classification, and Their Relation to Ore-Deposits with a Chapter on Meteorite. John Wiley \& Sons, New York.

[17] Middlemost, E.A.K. (1985) Magmas and Magmatic Rocks. Longman, London.

[18] Frost, B.R., Barnes, C.G., Collins, W.J., Arculus, R.J., Ellis, D.J. and Frost, C.D. (2001) A Geochemical Classification for Granitic Rocks. Journal of Petrology, 42, 2033-2048. https://doi.org/10.1093/petrology/42.11.2033

[19] Ryan, J.G. and Langmuir, C.H. (1993) The Systematics of Boron Abundances in Young Volcanic Rocks. Geochemica et Cosmochemica Acta, 57, 1489-1498. https://doi.org/10.1016/0016-7037(93)90008-K 
[20] Pearce, J.A. and Cann, J.R. (1973) Tectonic Setting of Basic Volcanic Rocks Determined Using Trace Element Analyses. Earth and Planetary Science Letters, 19, 290-300. https://doi.org/10.1016/0012-821X(73)90129-5

[21] Isfahani, F. and Sharifi, A. (1999) Geochemical Characteristics of Magmatic Rocks of Iran. Geological Survey of Iran, Tehran, 2, 1464 p.

[22] Hitzman, M.W., Oreskes, N. and Einaudi, M.T. (1992) Geological Characteristics and Tectonic Setting of Proterozoic Iron Oxide (Cu-U-Au-REE) Deposits. Precambrian Research, 58, 241-287. https://doi.org/10.1016/0301-9268(92)90121-4

[23] Aghanabati, A. (2004) The Geology of Iran. Geological Survey of Iran, Tehran, 586 p. (In Farsi)

[24] Samani, B.A. (1988) Metallogeny of the Precambrian in Iran. Precambrian Research, 39, 85106. https://doi.org/10.1016/0301-9268(88)90053-8

[25] Momenzadeh, M. (1987) Saline Deposits and Alkaline Magmatism, a Genetic Model. Geological Survey of Iran, 45, 1385-1495.

[26] Feiznia, S. (1993) Non-Terrigenous Sedimentary Rocks (Excluding Carbonates). Tehran University Publications, 262 p. (In Farsi)

[27] Moore, F. and Modabberi, S. (2003) Origin of Choghart Iron Oxide Deposit, Bafq Mining District, Central, Iran: New Isotopic and Geochemical Evidences. Journal of Scientific of Islamic Republic of Iran, 14, 259-269.

[28] Emami, M.H. (2000) Magmatism in Iran. Geological Survey of Iran, Tehran, 608 p. (In Farsi)

[29] Frietsch, F. and Perdahl, J.A. (1995) Rare Earth Elements in Apatite and Magnetite in Kiruna-Type Iron Ores and Some Other Iron Ore Types. Ore Geology Reviews, 9, 489-510. https://doi.org/10.1016/0169-1368(94)00015-G

[30] Kearey, P. and Vine, F.J. (1996) Global Tectonics. Blackwell Publication, London, 220 p.

[31] Hall, A. (1998) Igneous Petrology. Addison Wesley, London, 551 p.

[32] Raymond, L.R. (2002) Petrology: The Study of Igneous Sedimentary and Metamorphic Rocks. McGraw-Hill, Boston, 720 p.

[33] Sillitoe, R.H. (2003) Iron Oxide-Copper-Gold Deposits: An Andean View. Mineralium Deposita, 38, 787-812. https://doi.org/10.1007/s00126-003-0379-7

[34] Thorpe, R.S. and Smith, K. (1975) Mid Plate Volcanism in Geodynamics Today, a Review of the Earth's Dynamic Processes. Royal Society of London, 75-80.

[35] Hitzman, M.W. (2000) Iron Oxide-Cu-Au Deposits: What, Where, When and Why. In: Porter, T.M., Ed., Hydrothermal Iron Oxide Copper-Gold and Related Deposits: A Global Perspective, Vol. 1, PGC Publishing, Adelaide, 9-25. 
Submit or recommend next manuscript to SCIRP and we will provide best service for you:

Accepting pre-submission inquiries through Email, Facebook, LinkedIn, Twitter, etc. A wide selection of journals (inclusive of 9 subjects, more than 200 journals)

Providing 24-hour high-quality service

User-friendly online submission system

Fair and swift peer-review system

Efficient typesetting and proofreading procedure

Display of the result of downloads and visits, as well as the number of cited articles

Maximum dissemination of your research work

Submit your manuscript at: http://papersubmission.scirp.org/

Or contact ojg@scirp.org 